\title{
Geografija nemjesta; analiza Arena Centra u Zagrebu (makrorazina)
}

\author{
Karlo Mak \\ Gimnazija Antuna Gustava Matoša, Samobor, Hrvatska \\ e-mail:karlo.mak2@skole.hr
}

\author{
Martina Jakovčić \\ Prirodoslovno-matematički fakultet Sveučilišta u Zagrebu, Geografski \\ odsjek, Hrvatska \\ e-mail:mjakovci@geog.pmf.hr
}

SAŽETAK Na temelju Augéovog koncepta nemjesta osmišljen je interpretativni model analize trgovačkog centra (mikrorazina) te urbanog prostora koji se oko njega stvara (makrorazina). U svrhu funkcionalnog povezivanja tih dviju razina upotrijebljen je De Certeauov koncept potrošačke proizvodnje, prema kojem ljudi nisu tek pasivni konzumenti prostora, već nepredvidljivim prostornim ponašanjem sudjeluju u kreaciji nestabilnih prostornih veza i odnosa. Model je primijenjen na slučaju zagrebačkog Arena Centra. Ovaj rad donosi rezultate istraživanja na makrorazini, a temelji se na markerima tranzitnosti koje posjetitelji centra ostavljaju u prostoru. Oni su detektirani terenskim istraživanjem, kartiranjem, fotografiranjem i metodom promatranja. Dokazano je da trgovački centar tendira okolni prostor transformirati u nemjesto, kao i da nemjesta imaju sklonost agregiranja, o čemu svjedoče raznorodne prostorne oznake tranzitnosti, kao i dinamične morfološke, funkcionalne i demografske promjene.

Ključne riječi: nemjesto, potrošačka proizvodnja, trgovački centar, Arena, Lanište, Jaruščica. 


\section{Uvod}

U radu Maka i Jakovčić (2020.) redefinirano je poimanje koncepta nemjesta (engl. non-place), na osnovi čega je predstavljen interpretativni model analize prostora trgovačkog centra. Model je implementiran na primjeru Arena Centra u Zagrebu. Pritom je dokazano da taj trgovački centar funkcionira kao središte i društvene i ekonomske aktivnosti jugozapadnog dijela glavnoga grada. Kao takav, uspio je inicirati gradnju novih stambenih naselja u vlastitoj okolini. Stoga će se ovaj rad baviti prostorom koji se oko Arena Centra stvara, a s ciljem gradnje više razine gore spomenutog modela, tj. sa svrhom interpretacije širenja nemjesnih obilježja u okolni prostor. Taj je prostor ograničen Jadranskom avenijom na sjeverozapadu, Remetinečkom cestom na istoku odnosno Karlovačkom cestom na jugu - prometnicama koje predstavljaju vanjske granice triju naselja - Laništa, Jaruščice i Remetinečkoga gaja.

Interpretacija širenja nemjesnih obilježja u prostor oko Arena Centra bit će konstruirana kroz trijadu odnosa koju čine promet, stanovništvo i promjene u morfologiji naselja. Prometni tokovi (koji su spona s prostorom izvan naselja) pritom su ključan element tranzitnosti, a kako bi se moglo tvrditi da ih generira upravo dinamika posjećenosti trgovačkog centra, nužno je ispitati postojanje tragova u prostoru koji to sugeriraju. Na toj razini bit će važno ispitati i promjenu gustoće cestovne mreže od (najave) gradnje trgovačkog centra. Drugi element koji se ispituje, a dobrim se dijelom preklapa s prvim, čine promjene u morfologiji prostora. U užem smislu uključuje usporedbu $s$ drugim sličnim naseljima i promjene u korištenju zemljišta. Posljednji, ali nikako manje važan, element čini stanovništvo i njegova dinamika. Na kraju, integrativni faktor koji omogućuje funkcioniranje dviju razina modela kao koherentne cjeline čine posjetitelji trgovačkog centra. Upravo su posjetitelji ti koji povezuju mikro i makrorazinu. Stoga ćemo uvesti De Certeauov koncept potrošačke proizvodnje kako bismo pobliže objasnili u čemu se ta veza sastoji. Prema De Certeau, naglasak se premješta s potrošnje proizvoda i proizvoda općenito na ponašanje potrošača pod utjecajem potrošnje tih proizvoda. Time potrošnja zapravo postaje sekundarna proizvodnja (De Certeau, 2002). Potrošač svojom potrošnjom gradi svoj identitet. Konzumacija i konzumerizam kao način korištenja proizvoda, a time i prostora u kojem se taj proizvod nalazi time dolaze u prvi plan te de facto povezuju mikro i makrorazinu našeg proučavanog prostora.

\section{Teorijski okvir}

Iako se nemjesto definira kao prostor koji je lišen jedinstvenog identiteta, povijesti i odnosnosti (Augé, 2001.), Mak i Jakovčić (2020.) takvo određenje stavljaju pod znak upitnika te dopuštaju prisutnost navedenih obilježja. Istovremeno, ključnim momentom u određivanju nemjesta smatraju postojanje dinamičnosti i tranzitnosti u nekom prostoru, kao i prisustvo unificirajućih morfoloških obiljě̌ja koja nemjesto čine globalnim (bezličnim). Nadalje, tekstom provlače ideju kako ljudi nisu tek pasivni kon- 
zumenti prostora, već aktivno sudjeluju u kreaciji prostornih značenja, veza i odnosa unutar trgovačkog centra. Međutim, ta je kreacija prikrivena. Drugim riječima, moguće je govoriti o anonimnom stvaranju koje proizlazi iz prostornih praksi, pri čemu se fokus pomiče prema markerima devijacije koje određena ljudska aktivnost materijalizira u prostoru. Markeri devijacije pri tome podrazumijevaju promjene koje nastaju u prostoru, u našem slučaju u Arena Centru i njegovoj okolici, uslijed praksi kretanja i obrazaca ponašanja različitih od predviđenih. Množenjem takvih devijacija formira se svojevrsna „mreža antidiscipline“ (De Certeau, 2002.:35). Stoga je poželjno evaluirati otklon između proizvođačke i potrošačke proizvodnje, kako je naziva De Certeau. On se oslikava u tomu što „potrošači proizvode svojim označiteljskim praksama nešto što bi moglo poprimiti obličje linija hoda [...]. U tehnokratski sagrađenom prostoru, ispisanom i funkcionaliziranom, u kojem se oni kreću, njihove putanje oblikuju nepredvidljive rečenice." (De Certeau, 2002.:39). U našem konkretnom slučaju takvu nepredvidljivu cjelinu reprezentira nestabilna mreža kretanja koju formiraju (potrošačke) prakse, odnosno konstelacija pješačkih putova kao devijantna posljedica kretanja. Naime, prometni sustav grada često se za potrebe pješaka ne pokazuje dovoljnim, stoga oni stvaraju nove pravce (Walker, 2014.) nastojeći se nizom raznorodnih taktika osloboditi predvidljivih obrazaca kretanja (Hromadžić, 2008.). Jednom kad ljudi prepoznaju komparativne prednosti takvih, novoformiranih ruta, nastoje ih dalje koristiti, čime potpomažu njihovo oblikovanje povećavajući im vidljivost (Kohlstedt, 2016.). Takve neuređene putove nazivamo željenima (engl. desire paths), a poznati su i naprosto kao društveno proizvedene pješačke staze (Bramley, 2018.). Stoga se De Certeauov model potrošačke proizvodnje čini izuzetno korisnim alatom za funkcionalno povezivanje potencijalne nemjesnosti prostora koji se oko Arena Centra stvara s nemjesnim obilježjima samog Arena Centra.

Pozamašan broj autora bavio se trgovačkim centrima i njihovim funkcijama (Coleman, 2006.; Goss, 1993.; Lukić, 2002.; Lukić i Jakovčić, 2004.; Makgopa, 2016.), a mnogo je radova tematiziralo i međuodnos između izgradnje suburbanih trgovačkih centara i promjena u prostornoj strukturi trgovine u središnjim dijelovima gradova (Dickinson i Rice, 2010.; Lourenco i Bardi, 2007.; Tonković, 2015.). Međutim, utjecajem trgovačkog centra na neposrednu okolinu bavio se manji broj autora. Primjerice Heffner i Twardzik (2015.) identificirali su funkcionalne i prostorne promjene u organizaciji trgovine do kojih je došlo izgradnjom trgovačkih centara u izvangradskim prostorima južne Poljske. Sirpal (1994.) te Zhang i sur. (2019.) utvrdili su postojanje viših cijena stanovanja u neposrednoj blizini trgovačkih centara u Singapuru, tj. u Kini. Pritom trgovački centri istovremeno generiraju pozitivne i negativne učinke u okolni prostor; osiguravaju pogodnosti kupovine, dodatne sadržaje i funkcije, ali podrazumijevaju i buku, prometno zagušenje i povećanu emisiju ispušnih plinova (Sirpal, 1994.). Utjecaj trgovačkih centara na promet i prometnu infrastrukturu dokumentiran je u većem broju radova. O važnosti dovoljno velikog parkirališnog prostora za poslovni uspjeh trgovačkih centara raspravljaju Mingardo i Meerkerk (2012.), a s tim se u vezi dotiču 
morfoloških promjena u okolnom prostoru. Szczuraszek i Karwasz (2018.) izrađuju analitički model za ispitivanje količine cestovnog prometa koji generiraju trgovački centri te ističu čestu potrebu za proširenjem i/ili regulacijom prometne mreže u neposrednoj blizini centara. Savrasovs, Karakikes i Pticina (2019.) primjenjuju model mikroskopskog prometnog toka (engl. microscopic traffic flow model) kako bi procijenili utjecaj trgovačkog centra na okolni prostor. Taj se model obično koristi kako bi se ispitao utjecaj neke nove atrakcijske točke (trgovačkog centra) koja generira promet na postojeću prometnu infrastrukturu. Abutaleb i sur. (2020.) raspravljaju o količini prometa koju proizvode trgovački centri s pozicije modela tranzitno-orijentiranog razvoja (engl. transit-oriented development). Apostrofiraju važnost prostornog planiranja koje će $\mathrm{u}$ obzir uzeti promjene $\mathrm{u}$ intenzitetu prometa uslijed promjena broja posjetitelja centara.

\section{Hipoteze i metodologija}

Ovim će se istraživanjem provjeriti tvrdnja Maka i Jakovčić (2020.) da trgovački centar može poslužiti kao generator nemjesnosti u okolnom prostoru. S tim ciljem ispitat ćemo dinamiku morfoloških i demografskih promjena u prostoru oko Arena Centra te nastojati detektirati dokaze tranzitnosti čije je taj centar težište. Dvije osnovne polazne pretpostavke u istraživanju su: I. trgovački centar ima tendenciju prostor oko sebe transformirati u nemjesto i II. nemjesta imaju sklonost okupljanja, čime se intenzivira tranzitnost i prostorna dinamika.

Tako postavljen istraživački zadatak zahtijevao je kombinaciju nekoliko istraživačkih metoda. Značajan dio podataka prikupljen je terenskim istraživanjem, kartiranjem (pješački putovi), fotografiranjem (uporaba pješačkih putova, vizure novih zagrebačkih naselja) i metodom promatranja (uporaba pješačkih putova). Fotografirana su odabrana nova zagrebačka naselja koja se odlikuju nemjesnim obilježjima, te su kao takva usporediva s naseljima oko kompleksa koji čini sportska dvorana Arena Zagreb i trgovački centar Arena. Zatim su kartirani pješački putovi u neposrednoj blizini te selektirani oni za koje se, temeljem promatranja kretanja potrošača, može tvrditi da vode direktno prema ili od trgovačkog centra. Uz to, korišteni su odgovarajući demografski podaci (broj stanovnika i gustoća naseljenosti) te dio rezultata dobivenih anketnim istraživanjem predstavljenim u radu Maka i Jakovčić (2020.). Podaci vezani uz prostorni doseg utjecaja Arena Centra te uz morfološke promjene u njegovoj neposrednoj okolini analizirani su u MS Excelu, a kartografski su predočeni pomoću Google Eartha. 


\section{Rezultati i rasprava}

\subsection{Morfološke promjene}

Prvo stambeno naselje izgrađeno na prostoru koji je u fokusu ovoga rada bio je Remetinečki gaj. Naselje se počelo graditi u drugoj polovici 1950-ih, da bi se izgradnja intenzivirala početkom 1960-ih godina. Tek je potkraj 1980-ih počela izgradnja na Laništu (Mlinar, 2014.), no u vrlo limitiranom opsegu. Početkom 2000-ih gradnja je ponovo aktualizirana idejom formiranja naselja za braniteljsku populaciju, no doskora je stopirana sve do trenutka kad je odlučeno da će se graditi Arena Zagreb i Arena Centar. To je označilo prekretnicu i aktualizaciju izgradnje na Laništu, odnosno početak gradnje današnjeg naselja Jaruščica (Vitas, 2017.). Gradnju stambene i ostale infrastrukture ovdje promatramo kao preduvjet, ali i posljedicu ostvarivanja dinamike i tranzitnosti, odnosno nemjesnosti budući naselje nema nekih prepoznatljivih značajki koje bi ga izdvajale od drugih. Stambena infrastruktura, naime, podrazumijeva brojniju populaciju čiji se društveni život odvija u i oko trgovačkog centra, dok prometna infrastruktura vrlo plastično očitava dinamičnost i tranzitnost pravaca koji vode prema i od točke koja generira promet.

Analizom satelitskih snimaka prostora oko današnjeg Arena Centra 1968. i 2005. godine, uzimajući u obzir da se radi o vremenskom razdoblju od 37 godina, ne opažaju se značajnije prostorne promjene (slika 1). Usprkos povećanju udjela izgrađenih površina, i dalje dominiraju poljoprivredna zemljišta. Međutim, u samo pet narednih godina, dakle između 2005. i 2010., morfološke promjene toliko se intenziviraju da prostor oko Arena Centra zadobiva posve nova i drugačija obilježja (slika 2 i slika 3).

Slika 1.

Prostor oko današnjeg Arena Centra 1968. (lijevo) i 2005. godine (desno)
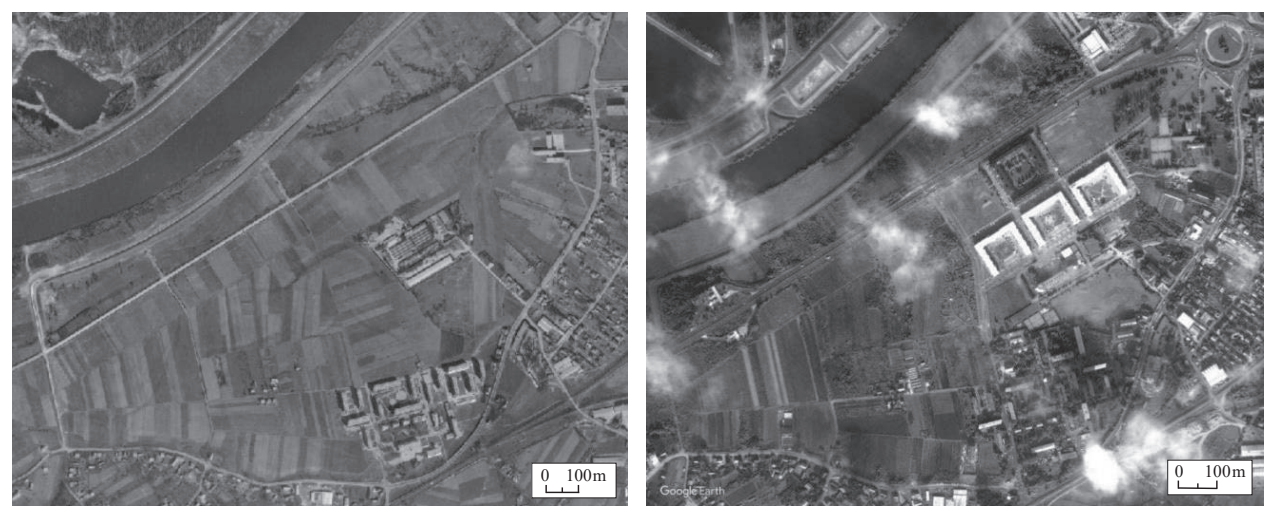

Izvori: MGIPU, 2019;; Google Earth, 2019. 
Slika 2.

Prostor oko današnjeg Arena Centra 2007. (lijevo) i 2008. godine (desno)
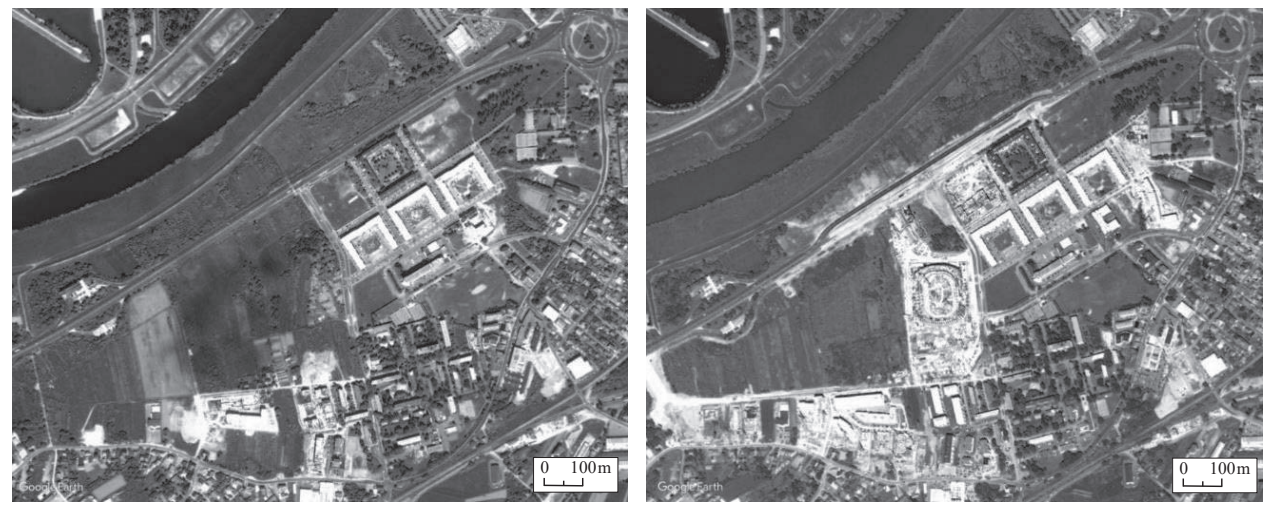

Izvor: Google Earth, 2019.

Slika 3.

Prostor oko današnjeg Arena Centra 2009. (lijevo) i 2010. godine (desno)
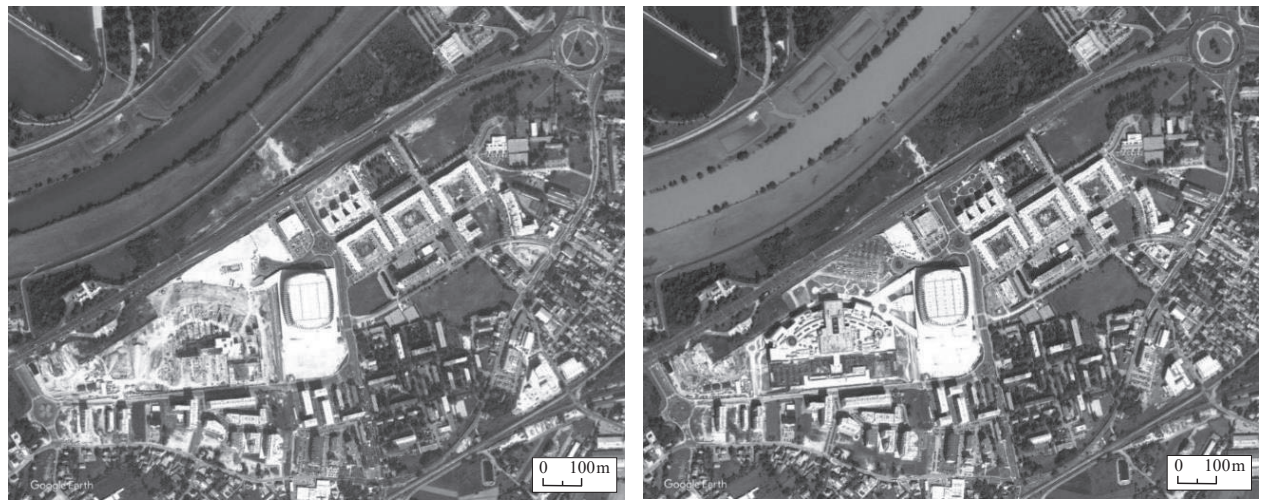

Izvor: Google Earth, 2019.

Odnos između površine izgrađenog i neizgrađenog prostora 1968. i 2019. godine gotovo je recipročan (tablica 1). Međutim, očigledno je da značajnije promjene u morfologiji prostora koincidiraju s 2005. godinom, neposredno pred najavu izgradnje kompleksa Arena - Arena. 
Tablica 1.

Odnos neizgrađenog i izgrađenog prostora u naseljima oko Arena Centra 1968., 2005. i 2019. godine

\begin{tabular}{|l|c|c|c|c|}
\hline \multirow{2}{*}{ Godina } & \multicolumn{2}{|c|}{ Neizgrađen prostor } & \multicolumn{2}{c|}{ Izgrađen prostor } \\
\cline { 2 - 5 } & $\mathrm{m}^{2}$ & $\%$ & $\mathrm{~m}^{2}$ & $\%$ \\
\hline 1968. & 754945 & 85,6 & 127165 & 14,4 \\
\hline 2005. & 542739 & 61,5 & 339371 & 38,5 \\
\hline 2019. & 112701 & 12,8 & 769409 & 87,2 \\
\hline
\end{tabular}

Izvori: MGIPU, 2019.; Google Earth, 2019.

Morfološke promjene uvjetovale su prenamjenu zemljišta. Dok je još 2011. godine određeni dio zemljišta bio namijenjen u poljoprivredne svrhe ili bio neuređen, već je dvije godine kasnije planirano da će ga zamijeniti prostor stambene, komunalne i dijelom javno-društvene namjene (ZIPP, 2019.). Također, dio prostora zapadno od Arena Centra koji je 2011. godine svrstan u kategoriju predviđenu za „transformaciju“, već je 2013. prenamijenjen u gospodarsko zemljište, da bi sredinom svibnja 2019. godine na njemu bio izgrađen i otvoren Arena Park ${ }^{1}$.

Nakon što je dokazana dinamičnost morfoloških promjena, vratit ćemo se načas na još jedno bitno obilježje nemjesta - njihovu vezu s globalizacijskim tokovima (Augé, 2001.), odnosno bezličnost. Nemjesta su sveprisutna i globalna te obilježena visokom razinom uniformnosti, čime se umanjuje njihova lokalna (historijska) dimenzija. Stoga posjetitelj nemjesta može imati dojam da se nalazi bilo gdje na svijetu (Menatti, 2011.; Zlatar, 2011.). Te ćemo tvrdnje provjeriti tako da usporedimo vizure novih zagrebačkih naselja - budući da je sa sigurnošću moguće tvrditi da se u razdoblju njihove izgradnje ostvarila situacija supermoderniteta ${ }^{2}$ - sa stambenom gradnjom oko kompleksa Arena - Arena (slika 4).

${ }^{1}$ Maloprodajni park čija se ponuda temelji na trgovinama specijaliziranim za dom, obitelj i sport. Obilježava ga karakteristična open-air struktura s parkiralištem neposredno ispred prodajnih objekata (Arena Park, 2019.).

2 Ostvarivanje stanja supermoderniteta (vremensko i prostorno preobilje te individualizacija referencija) preduvjet je nastanka nemjesta (Augé, 2001.). 
Slika 4.

Dio stambenog naselja Jaruščica južno od kompleksa Arena - Arena (18. svibnja 2019.)

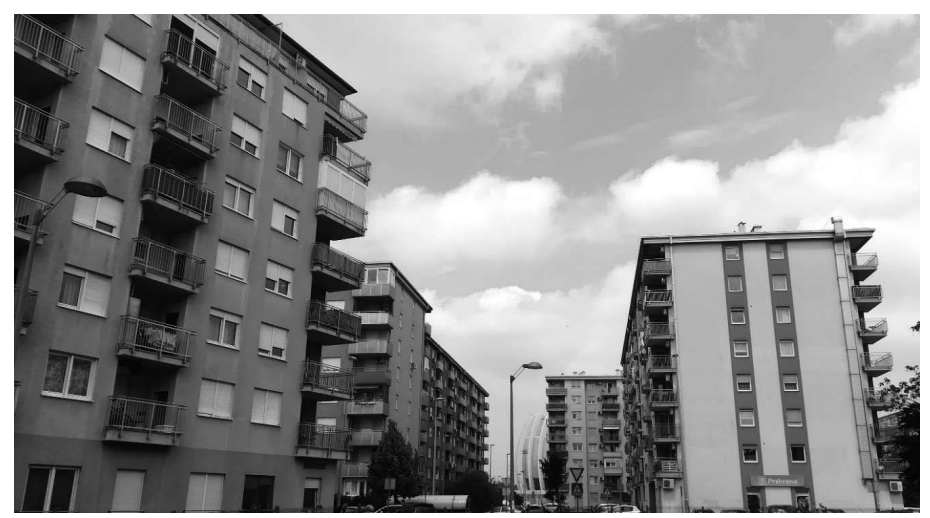

Izvor: Vlastita fotografija.

Novim zagrebačkim naseljima smatramo ona nastala nakon 2000. godine. Mlinar (2009.) je na osnovi specifičnih kriterija izdvojio devet takvih dijelova grada, među ostalim Sopnicu - Jelkovec, Podbrežje, Špansko - Oranice (slika 5) i Vrbane III (slika 6). Njihova je urbanistička shema u pravilu ortogonalna, od čega blagi otklon predstavlja tek naselje Vrbani III s ortogonalno-zakrivljeno-radijalnom (Mlinar, 2009.). U svim su spomenutim naseljima građene stambene zgrade pravokutnog tlocrta, pri čemu varira jedino visina katova (četiri do osam), a ni u jednom nisu predviđene ni izgrađene obiteljske kuće. U prizemlju dijela stambenih zgrada nalaze se poslovni lokali namijenjeni bilo za trgovinske bilo za ostale svrhe. Istovjetna obilježja ima i stanogradnja južno od Arene Zagreb i Arena Centra. Doista, neupućenom se posjetitelju može činiti da se nalazi u bilo kojem od spomenutih naselja, čime su (barem na razini Zagreba) potvrđena njihova nemjesno-standardizirana obilježja.

Slika 5.

Dio stambenog naselja Špansko - Oranice (31. svibnja 2019.)

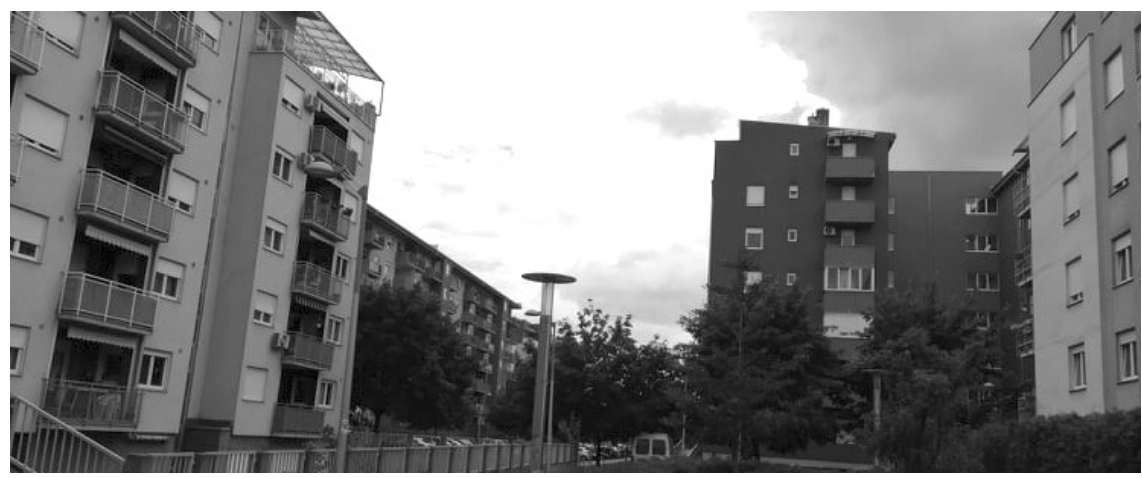

Izvor: Vlastita fotografija 
Slika 6.

Dio stambenog naselja Vrbani III (31. svibnja 2019.)

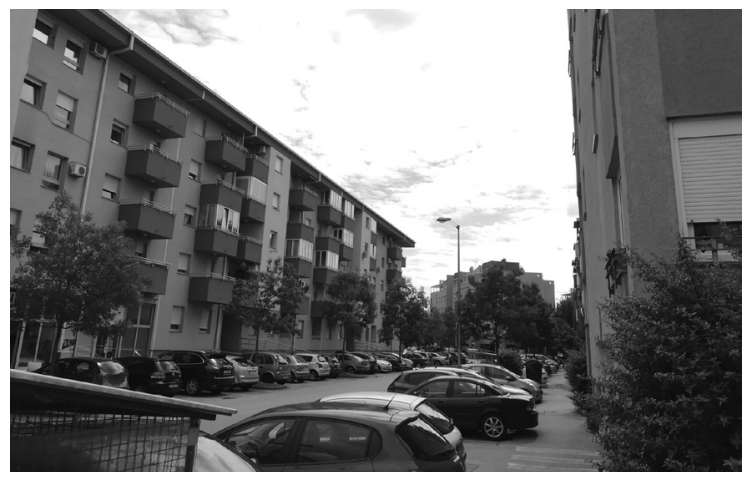

Izvor: Vlastita fotografija.

S druge strane, naselje Remetinečki gaj ima svoju specifičnu povijest, koja stvara karakterističan osjećaj mjesta. Njegova socijalistička arhitektura ne dozvoljava šetaču percepciju da je bilo gdje drugdje na svijetu, budući da ona nije univerzalistička. Naselje je, među ostalim, obilježeno Jugomontovim stambenim zgradama tipa JU-60 i JU-61, čija su pročelja obložena limom (Mlinar, 2014.) - otuda figurativni naziv „limenke" (slika 7). Prema tomu, obilježje univerzalnosti nemjesta ovdje nije očitovano. ${ }^{3}$ Ali to ne znači da Remetinečki gaj ne poprima ostale karakteristike nemjesta, napose one tranzitne koje su najuže vezane uz prometne tokove.

Slika 7.

Jugomontova stambena zgrada u Remetinečkom gaju (18. svibnja 2019.)

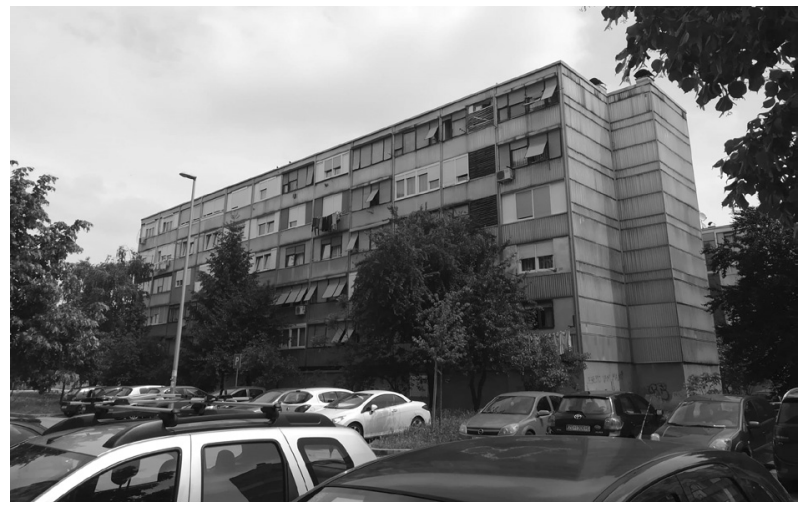

Izvor: Vlastita fotografija.

${ }^{3}$ Iako „limenke“ postoje i u nekoliko drugih zagrebačkih naselja (npr. Zapruđe ili Borongaj), ne možemo tvrditi da su one odraz unificiranosti na globalnoj razini. K tomu, u vrijeme njihove gradnje još se nisu stekli uvjeti za realizaciju supermodernosti, inicijalne pretpostavke za nastanak nemjesta. 


\subsection{Tranzitna obilježja}

Baveći se morfološkim promjenama u smislu porasta izgrađenosti i prenamjene zemljišta te promjenom strukture stambene infrastrukture, djelomično su iz vida ispušteni posjetitelji Arena Centra, oni koji od Laništa, Remetinečkoga gaja i Jaruščice stvaraju dinamično-tranzitni prostor i koji, u konceptualnom smislu, povezuju dvije osmišljene razine predstavljenog interpretativnog modela. Za dvije trećine posjetitelja koji u trgovački centar dolaze osobnim automobilom (Mak i Jakovčić, 2020.) marker tranzitnosti predstavlja postojeća prometna infrastruktura. ${ }^{4}$ Pred početak gradnje Arene Zagreb i Arena Centra (2005. godine) na okolnom je području bilo tek 6,2 kilometara cestovne mreže, što bi u granicama današnjih Karlovačke i Remetinečke ceste odnosno Jadranske avenije iznosilo $6,5 \mathrm{~km} / \mathrm{km} 2$ (Google Earth, 2019.). Jednom od pretpostavki rada tvrdimo da trgovački centar ima tendenciju oko sebe okupljati ostale pojavne oblike nemjesta. Doista, nepunih petnaest godina od početka gradnje kompleksa Arena - Arena prostorna gustoća prometne mreže gotovo je udvostručena $(12,1 \mathrm{~km} / \mathrm{km} 2)$ (Google Earth, 2019.). Time su stvorene pretpostavke za povećanje prostorne dinamike i tranzitnosti u okolnim naseljima. Međutim, ne postoji sustavno brojanje prometa u prostoru koji je u fokusu ovoga rada. Stoga ćemo se za problematiziranje promjene intenziteta prometa poslužiti istraživanjima provedenim na obližnjem remetinečkom rotoru (tablica 2). Spomenuto kružno raskrižje otvoreno je 1985. godine. Njegov predviđeni kapacitet iznosio je 50.000 vozila dnevno. Najkasnije 2005. godine taj je broj premašen, dosegnuvši čak 68.550 vozila (Klisura, 2017.). Promet je više nego pojačan u tijeku i nakon izgradnje Arene Zagreb, Arena Centra i novih stambenih naselja (Balija, 2018.; Mlinar, 2014.) te je ustaljen na oko 100.000 vozila dnevno (Klisura, 2017.). Međutim, ono na osnovi čega možemo tvrditi da upravo trgovački centar intenzivira promet jest povećanje broja vozila na rotoru povezanih s Jadranskom avenijom (4,5\%) i Remetinečkom cestom $(14,7 \%)$, tj. prometnicama koje vode direktno do/od Arena Centra.

Tablica 2.

Cjelodnevno brojanje prometa na remetinečkom rotoru 24. listopada 2008. i 14. ožujka 2017. godine

\begin{tabular}{|l|c|c|c|}
\hline Privoz & 24. listopada 2008. & 14. ožujka 2017. & Indeks \\
\hline Jadranski most & 29,557 & 26,064 & 88,2 \\
\hline Avenija Dubrovnik & 34,504 & 34,019 & 98,6 \\
\hline Remetinečka cesta & 11,074 & 12,696 & 114,7 \\
\hline Jadranska avenija & 23,888 & 24,963 & 104,5 \\
\hline Ukupno & 99,023 & 97,742 & 98,7 \\
\hline
\end{tabular}

Izvori: Pološki, 2009.; Klisura, 2017.

4 Čak 67,3 \% posjetitelja dolazi osobnim automobilom, 25,5 \% javnim prijevozom, a tek 4,4\% pješači (Mak i Jakovčić, 2020.). 
Dosad smo utvrdili da su funkcionalni sklop Arena - Arena te gradnja okolnih naselja prouzrokovali gradnju nove prometne infrastrukture. Dakle, došlo je do agregiranja nemjesta, čime je čitav taj prostor poprimio nemjesna obilježja, kako pojačanim intenzitetom prometa, tako i pratećom cirkulacijom razmjerno velikog broja posjetitelja trgovačkog centra. Međutim, posjetitelji koji u Arena Centar dolaze osobnim automobilom tek su dio cjelovite konstelacije veza i odnosa koja je mnogo kompleksnija. Javnim prijevozom u trgovački centar dolazi četvrtina posjetitelja. Jednako kao i u slučaju posjetitelja koji dolaze osobnim automobilom, prostorni marker većeg dijela puta korisnika javnoga prijevoza predstavlja postojeća prometna infrastruktura. Međutim, s obzirom na prostorni razmještaj autobusnih stajališta ${ }^{5}$, završetak tih putovanja nužno je pješačenje. Osobe koje u Arena Centar dolaze isključivo pješice čine manje od $5 \%$ posjetitelja centra. Dakle, nešto manje od trećine svih ispitanika barem dio svog puta do trgovačkog centra pješači (anketno istraživanje, Mak, 2019.). Ta nam je informacija neobično važna za analizu tragova koje pješaci u prostoru ostavljaju, a koji svjedoče o dinamici i tranzitnosti. Stoga valja pomno razmotriti disperziranost njihove pojave. Mislimo prije svega na pješačke putove (slika 8) koji obično sijeku travnate ili zemljane površine.

Slika 8.

Pješački put južno od Arena Centra (21. svibnja 2019.)

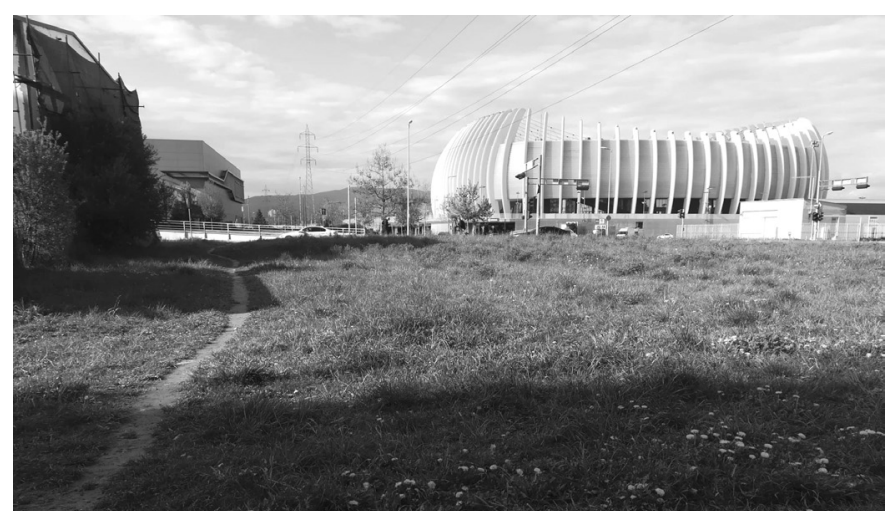

Izvor: Vlastita fotografija.

Pješački putovi temeljni su dio urbanog okoliša budući da je završni dio gotovo svakog putovanja upravo pješačenje. Pri tom je odlučujući faktor za odabir pješačke rute odnos između uloženog truda i vremena potrebnog da se pređe određena udaljenost, odnosno odabire se najkraći mogući put (Kudinov i sur., 2018.). Ono što je važno

${ }^{5} \mathrm{U}$ uzorku ispitanika nije zabilježen nijedan posjetitelj koji je došao bilo vlakom bilo tramvajem (Mak i Jakovčić, 2020.). Stoga željezničke i tramvajske stanice nisu problematizirane. Zbog obnove remetinečkog rotora i ponovnog puštanja u promet tramvajske pruge može se, doduše, očekivati nemali dio posjetitelja centra koji će koristiti tramvajski prijevoz te nešto smanjeni udio korisnika autobusnog prijevoza. 
za analizu prostora oko Arena Centra kao nemjesta, a povezano s takvim putovima, činjenica je da oni svjedoče o kretanju, o postojanju kontinuiranog prostornog toka ljudi mimo predviđenih ruta/pravila. Kao takvi nedvojbeno govore u prilog tranzitnosti i dinamike u okolici centra. Također činjenica da pri gradnji centra nisu planirani putevi za pješake, već isključivo za automobile, a pješačke staze dodane su naknadno na temelju utabanih puteva koje su stvorili sami pješaci govori nam u prilog nemjesnosti, postmodernosti ili u najkraćim crtama tehnologiziranosti samog centra, ali i okolnog prostora koji ne predviđa uporabu od „živih ljudi“, već isključivo tehnologije, odnosno automobila. Neplaniranje puteva također nam ukazuje i na činjenicu da centar nije percipiran kao sastavni dio okolnog prostora i naselja uz koja se nalazi.

Unatoč maloj površini proučavanog prostora $(0,88 \mathrm{~km} 2)$, ukupna duljina alternativnih pješačkih putova ovdje iznosi čak 2887 metara (slika 9). Od toga, čak je 2351 metar, ili 81,4 \% direktno povezano s Arena Centrom. Odabirom alternativnih ruta pješaci povećavaju broj mogućnosti u odnosu na broj utvrđen prostornim poretkom (De Certeau, 2002.).

Slika 9.

Pješački putovi u neposrednoj okolini Arena Centra (svibanj, 2019.)

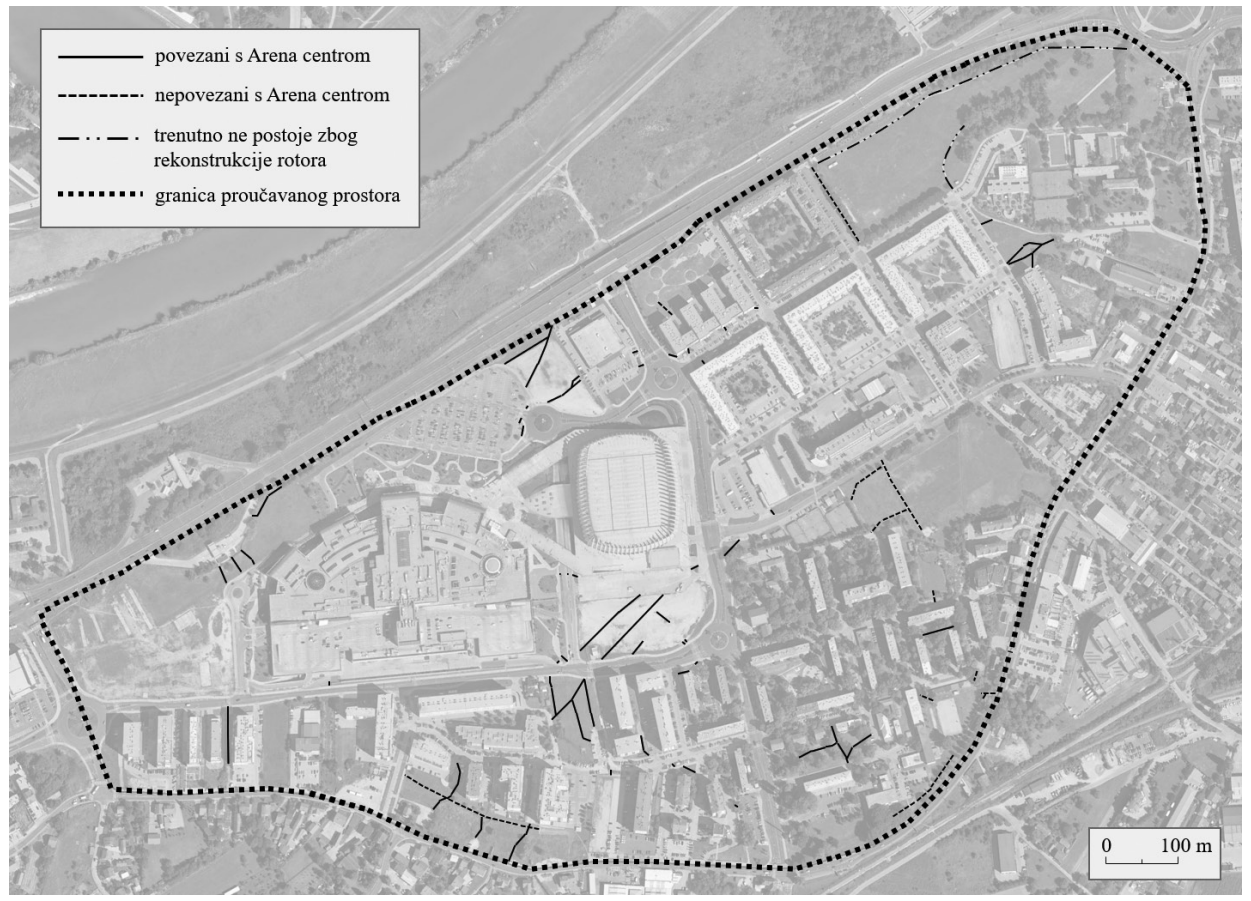

Izvori: Google Earth, 2019.; Terensko istraživanje. 
Prostorna gustoća spomenutih pješačkih putova iznosi $2664,6 \mathrm{~m} / \mathrm{km} 2$. Pribroje li se tomu 874 metra putova koji su nekad postojali, ali su uslijed radova na rekonstrukciji remetinečkog rotora eliminirani, dobiva se prostorna gustoća od čak 3655,8 m/ $\mathrm{km} 2$. Naime, opravdano je pretpostaviti da će se i nakon završetka tih radova ponovo formirati nekadašnje rute s obzirom na to da je na službenim stranicama Grada Zagreba eksplicitno navedeno da će se obnovom rotora tek „otvoriti mogućnost izgradnje tramvajske pruge do Laništa“" (Grad Zagreb, 2019.), a ne da će se u taj projekt uistinu i krenuti.

Pješačkim putovima hodači ispisuju urbani tekst, a međuodnos tih ispisa oblikovan je od fragmenata putovanja (De Certeau, 2002.). Njime je na specifičan način modeliran prostor naselja oko Arena Centra i naznačena dinamika njima imanentnih prostornih tokova (pješački putovi) kao bitna i od njih nedjeljiva odrednica. Drugim riječima: „Povijest započinje na razini tla, $s$ koracima. [...]. Njihovo je rojenje neizbrojiv skup pojedinosti. Igre koračaja oblikuju prostor. One spleću [ne]mjesta. U tom smislu, pješačka kretanja tvore jedan od onih stvarnih sustava čije postojanje uistinu čini grad, ali koji nemaju nikakve tjelesne zapremnine. Oni se ne lokaliziraju, nego se šire prostorom" (De Certeau, 2002.:161.).

De Certeau (2002.) se kritički odnosi spram kartografskog predočavanja prostornih praksi. Ističe da se ucrtani pravci hodanja odnose tek na ono što pripada prošlosti i više ne postoji. Doista, ucrtane krivulje bilježe dosadašnje prakse hodača i vezane su za specifični vremenski odsječak. K tomu, nije moguće kartografski posvjedočiti o nečemu čega nije bilo ili što će tek biti. Ali, na temelju evidentiranja perzistencije hodanja eksplicitno određenim putovima (slika 10), moguće je detektirati prisutnost praksi u sadašnjosti i njihovo potencijalno opstojanje u (bližoj) budućnosti. Nadalje, kartografskim se prikazivanjem ne gubi čin prolaženja niti je njime preostatak kretanja „smješten u ne-vrijeme projicirane površine“, čiji je učinak tobože napraviti „nevidljivom radnju koja ju je omogućila“ (De Certeau, 2002.:162.). Štoviše, čin se prolaženja evidentira, pri čemu krivudave linije predstavljaju prostorni tok i asociraju na koračaje, ma koliko takva reprezentacija bila sadržajno siromašnija od stvarnih praksi hodača. Stoga se nije moguće složiti s francuskim povjesničarom kad tvrdi da trag na karti „očituje (pohlepno) svojstvo geografskog sustava da djelovanje preobrazi u čitljivost“ bacajući „u zaborav jedan način da se bude u svijetu“ (De Certeau, 2002.:162.). Naposljetku, kako drugačije zorno prikazati takvu prostornu konstelaciju? Tekstom? Fotografijom? Video isječkom? Ionako nije poznata forma reprezentacije koja bi vjerno korespondirala sa zbiljom. 
Slika 10.

Uporaba pješačkih putova istočno od Arena Centra (7. svibnja 2019.)

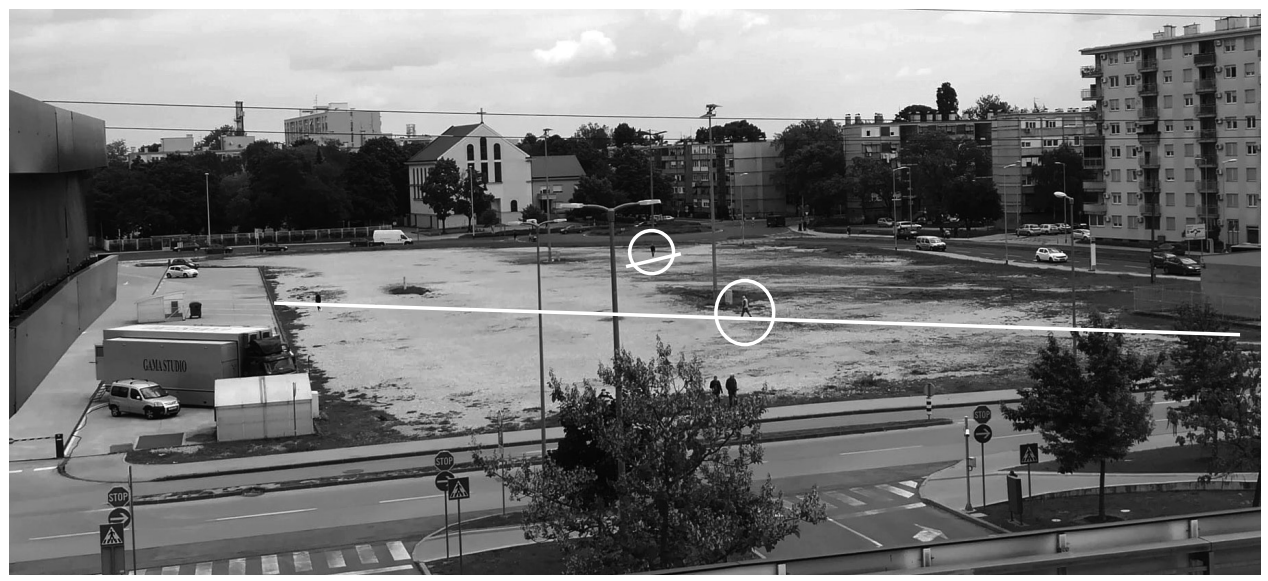

Izvor: Vlastita fotografija

Možemo li govoriti o prostornom obuhvatu nemjesnih obilježja koje generira Arena Centar? Granice utjecaja nemjesnosti zasigurno nisu maksimalne zabilježene udaljenosti s koje posjetitelji centra dolaze (prostor čitave Hrvatske te mjesta u Sloveniji i $\mathrm{BiH}$ bliža hrvatskoj granici), a logički je neodrživo tvrditi da se ta granica poklapa s prosječnom $(52,2 \mathrm{~km})$ ili medijalnom $(12,9 \mathrm{~km})$ udaljenošću mjesta stanovanja posjetitelja od Arena Centra. Naime, u tom radijusu postoje i drugi objekti koji svojim funkcijama privlače stanovništvo. Stoga bi smislena granica morala u obzir uzeti prostorne tragove tranzitnosti koji vode do Arena Centra, ali ne i prometnu infrastrukturu - jer samo postojanje prometnica ne govori nužno o dinamici i tranzitnosti. Drugim riječima, u obzir valja uzeti udaljenost s koje pješaci dolaze u trgovački centar te u tom radijusu kartirati pješačke putove. Sve dokle je moguće tvrditi da većina tako kartiranih pješačkih ruta nedvojbeno vodi do Arena Centra, taj je prostor zasigurno pod njegovim tranzitno-nemjesnim utjecajem.

\subsection{Demografska dinamika}

Morfološko-funkcionalne promjene kroz koje je prošao prostor oko cjeline Arena - Arena uslijed gradnje sportske dvorane i trgovačkog centra za sobom neminovno povlače poprilične demografske fluktuacije. Naime, u nemalom je broju europskih gradova koncentracija trgovačkih funkcija u predgrađima, pri čemu ovdje primarno mislimo na trgovačke centre, intenzivirala njihovu populacijsku dinamiku (Tonković, 2015.).

Doista, gradska četvrt Novi Zagreb - zapad u međupopisnom je razdoblju 2001./2011., uz Stenjevec, zabilježila najvišu stopu promjene broja stanovnika u glavnome gradu 
(tablica 3). Budući da je gustoća naseljenosti te gradske četvrti za urbane prilike još uvijek razmjerno niska te s obzirom na dosadašnje demografske trendove i mogućnosti koje taj prostor pruža, valja pretpostaviti daljnji trend koncentracije stanovništva.

Najviša stopa promjene broja stanovnika prema jedinicama mjesne samouprave gradske četvrti Novi Zagreb - zapad koincidira s blizinom kompleksa Arena - Arena (OZS, 2005.; OZS, 2014.). Istovjetno stanje zamjetljivo je u pogledu gustoće naseljenosti. Takvi demografski trendovi na Laništu i Remetincu odraz su nemjesnosti koja se reflektira u dinamičnim populacijskim kretanjima. $\mathrm{K}$ tomu, posredstvom uvida u prenamjenu zemljišta te recentnih morfoloških promjena, moguće je zaključiti kako se značajno promijenila i socioekonomska struktura stanovništva tih jedinica mjesne samouprave.

Tablica 3.

Broj stanovnika i gustoća naseljenosti zagrebačkih gradskih četvrti 2001. i 2011.

\begin{tabular}{|c|c|c|c|c|c|}
\hline \multirow[b]{2}{*}{ Gradska četvrt } & \multicolumn{2}{|c|}{ Stanovništvo (2001.) } & \multicolumn{2}{|c|}{ Stanovništvo (2011.) } & \multirow{2}{*}{$\begin{array}{c}\text { Stopa (\%) } \\
\text { promjene } \\
\text { broja } \\
\text { stanovnika }\end{array}$} \\
\hline & $\begin{array}{c}\text { Broj } \\
\text { stanovnika }\end{array}$ & $\begin{array}{c}\text { Gustoća } \\
\text { naseljenosti } \\
\left(\text { stan./ } / \mathrm{km}^{2} \text { ) }\right.\end{array}$ & $\begin{array}{c}\text { Broj } \\
\text { stanovnika }\end{array}$ & $\begin{array}{c}\text { Gustoća } \\
\text { naseljenosti } \\
\left(\text { stan./ } / \mathrm{km}^{2}\right)\end{array}$ & \\
\hline Donji Grad & 45108 & 14936 & 37024 & 12260 & $-17,92$ \\
\hline Gornji Grad - Medveščak & 36384 & 3571 & 30962 & 3038 & $-14,90$ \\
\hline Trnje & 45267 & 6150 & 42282 & 5745 & $-6,59$ \\
\hline Maksimir & 49750 & 3323 & 48902 & 3267 & $-1,70$ \\
\hline Pešćenica - Žitnjak & 58283 & 1651 & 56487 & 1600 & $-3,08$ \\
\hline Novi Zagreb - istok & 65301 & 3948 & 59055 & 3570 & $-9,56$ \\
\hline Novi Zagreb - zapad & 48981 & 782 & 58103 & 928 & 18,62 \\
\hline Trešnjevka - sjever & 55358 & 9528 & 55425 & 9540 & 0,12 \\
\hline Trešnjevka - jug & 67162 & 6825 & 66674 & 6776 & $-0,73$ \\
\hline Črnomerec & 38762 & 1600 & 38546 & 1591 & $-0,56$ \\
\hline Gornja Dubrava & 61388 & 1525 & 61841 & 1536 & 0,74 \\
\hline Donja Dubrava & 35944 & 3325 & 36363 & 3364 & 1,17 \\
\hline Stenjevec & 41257 & 3387 & 51390 & 4219 & 24,56 \\
\hline Podsused - Vrapče & 42360 & 1171 & 45759 & 1265 & 8,02 \\
\hline Podsljeme & 17744 & 299 & 19165 & 322 & 8,01 \\
\hline Sesvete & 59212 & 358 & 70009 & 424 & 18,23 \\
\hline Brezovica & 10884 & 85 & 12030 & 94 & 10,53 \\
\hline Grad Zagreb (ukupno) & 779145 & 1215 & 790017 & 1232 & 1,40 \\
\hline
\end{tabular}

Izvori: OZS, 2005.; OZS, 2014. 


\section{Zaključak}

Primjena osmišljenog konceptualnog modela omogućila je analizu promjena kojima je zahvaćena bliža okolica Arena Centra. Testiranjem dviju polazišnih pretpostavki provjereno je generira li trgovački centar nemjesna obilježja u okolni prostor te, pod uvjetom da je takva obilježja moguće detektirati, dokle sežu granice njihova utjecaja.

Visoki intenzitet morfoloških promjena utvrđen je izrazitim povećanjem izgrađenosti istraživanog prostora od (najave) gradnje kompleksa Arena - Arena te s time povezanom prenamjenom zemljišta. Osim u slučaju Remetinečkoga gaja, istaknuta su nemjesno-standardizirana morfološka obilježja novooformljenih naselja oko Arena Centra u odnosu na nova stambena naselja u Zagrebu. Nadalje, porast intenziteta tranzitnosti dokazan je povećanjem prostorne gustoće prometne infrastrukture te intenzifikacijom prometa na remetinečkom rotoru, kojemu su ishodište/odredište one prometnice koje vode direktno do/od Arena Centra. Osim toga, evidentirani su prostorni markeri pješaka koji se kreću u otklonu spram predviđenoj infrastrukturi. Budući da je preko četiri petine takvih pješačkih ruta moguće direktno povezati $s$ Arena Centrom, opravdano je tvrditi da je upravo trgovački centar generator netom opisane tranzitnosti. Naposljetku, morfološke promjene u promatranom prostoru za sobom neminovno povlače poprilične demografske fluktuacije. Gradska četvrt Novi Zagreb - zapad u međupopisnom je razdoblju 2001./2011., izuzev Stenjevca, zabilježila najvišu stopu promjene broja stanovnika u glavnome gradu. Nadalje, najviša stopa promjene prema jedinicama mjesne samouprave gradske četvrti Novi Zagreb - zapad koincidira s blizinom kompleksa Arena - Arena. Istovjetno stanje zamjetljivo je u pogledu gustoće naseljenosti te promjeni socioekonomske strukture stanovništva. Takvi demografski trendovi na Laništu i u Remetincu odraz su nemjesnosti koja se reflektira $\mathrm{u}$ dinamičnim populacijskim kretanjima.

Rezultatima prezentiranima u radu Maka i Jakovčić (2020.) te potvrđivanjem polazišnih hipoteza ovoga teksta utvrđeno je da Arena Centar u svojoj punini funkcionira kao nemjesto - dinamičan i tranzitni prostor na mikrorazini samog centra, kao i na makrorazini koju sačinjava s okolnim naseljima. Budući da su se za to nesumnjivo stekli uvjeti, Arena Centar okolni prostor, u radijusu ne većem od onog s kojeg posjetitelji dolaze pješice, zasigurno opskrbljuje nemjesnim obilježjima. Pritom ga lišava osjećaja lokalnosti, standardizira njegove stambene odlike te doprinosi intenzifikaciji tranzitnosti i prostorne dinamike. 


\section{Literatura}

1. Abutaleb, A.; McDougall, K.; Basson, M.; Hassan, R.; Mahmood, M. (2020). The Impact of Transit-Oriented Shopping Mall Developments (TOSMDs) on Metro Station Ridership: Dubai Metro Redline. Urban Rail Transit, 6 (1): $157-$ 170.

2. Augé, M. (2001). Nemjesta: Uvod u moguću antropologiju supermoderniteta. Karlovac: Naklada Društva arhitekata, građevinara i geodeta.

3. Bramley, E. V. (2018). Desire paths: the illicit trails that defy the urban planners. The Guardian, listopad 2018. https://www.theguardian.com/cities/2018/ oct/05/desire-paths-the-illicit-trails-that-defy-the-urban-planners. (Pregledano 17. travnja 2019.)

4. Coleman, P. (2006). Shopping Environments. Evolution, Planning and Design. Oxford: Elsevier.

5. De Certeau, M. (2002). Invecnija svakodnevice. Zagreb: Naklada MD.

6. Dickinson, A. and Rice, M. D. (2010). Retail Development and Downtown Change: Shopping Mall Impacts on Port Huron, Michigan. Applied Research in Economic Development, 7 (1): 2-13.

7. Goss, J. (1993). The Magic of the Mall: An Analysis of Form, Function, and Meaning in the Contemporary Retail Built Environment. Annals of the Associattion of American Geographers, 83 (1): 18-47.

8. Heffner, K. and Twardzik, M. (2015). The Impact Of Shopping Centers In Rural Areas And Small Towns In The Outer Metropolitan Zone (The Example OfThe Silesian Voivodeship). European Countryside, 2: 87-100. DOI: 10.1515/ euco-2015-0006.

9. Hromadžić, H. (2008). Konzumerizam. Potreba, životni stil, ideologija. Zagreb: Naklada Jesenski i Turk.

10. Klisura, M. (2017). Optimizacija raskrižja s kružnim tokom prometa Jadranska avenija - Avenija Dubrovnik u gradu Zagrebu. (Neobjavljen diplomski rad). Zagreb: Fakultet prometnih znanosti.

11. Kohlstedt, K. (2016). Least Resistance: How Desire Paths Can Lead to Better Design. 99\% Invidible. https://99percentinvisible.org/article/least-resistancedesire-paths-can-lead-better-design/. (Pregledano 17. travanja 2019.)

12. Kudinov, S.; Smirnov, E.; Malyshev, G.; Khodenko, I. (2018). Planning Optimal Path Networks Using Dynamic Behavioral Modeling, in: Yong S. et al (Eds.). Computational Science - ICCS 2018. Cham: Springer.

13. Lourenco, J. and Bardi, T. (2007). Shopping Areas and Strategic Planning Congress Report. 43rd ISOCARP Congress: Urban Trialogues. http://www.isocarp.net/. (Pregledano 23. travnja 2019.)

14. Lukić, A. (2002). Socijalne funkcije trgovačko-poslovnog središta: Primjer Centra Kaptol u Zagrebu. Hrvatski geografski glasnik, 64 (1): 73-94.

15. Lukić, A. and Jakovčić, M. (2004). Location and function of hypermarkets and shopping centers in Zagreb. Dela, 22: 39-54. 
16. Mak, K. i Jakovčić, M. (2020). Geografija nemjesta: analiza Arena Centra u Zagrebu (mikrorazina). Sociologija i prostor, 58 (2): 189-210. DOI: 10.5673/ sip.58.2.4.

17. Makgopa, S. (2016). Determining shopping mall visitors' perceptions on mall attributes. Problems and Perspectives in Management, 14 (39): 522-527.

18. Menatti, L. (2011). From Non-Place to Rhizome: A Geophilosophical Analysis of Contemporary Globalized Space. Environment, Space, Place, 3 (2): 22-50. DOI: 10.7761/ESP.3.2.22

19. Mingardo, G. and Meerkerk, J. (2012). Is parking supply related to turnover of shopping areas? The case of the Netherlands. Journal of Retailing and Consumer Service, 19 (2): 195-201. DOI: 10.1016/j.jretconser.2011.12.001

20. Mlinar, I. (2009). Zagrebačka stambena naselja nakon 2000. godine. Prostor. Znanstveni ćasopis za arhitekturu i urbanizam, 37 (1): 159-169.

21. Mlinar, I. (2014). Remetinečki gaj-Početak sustavne urbanizacije novozagrebačkog područja. Zagreb: Centar za kulturu Zagreb - Sveučilište u Zagrebu.

22. Savrasovs, M.; Karakikes, I. and Pticina, I. (2019). Shopping Mall Environmental Impact Evaluation Based on Microscopic Traffic Flow Simulation, in: Endrjukaite, T. et al (Eds.). Information Modelling and Knowledge Bases XXX (312). Amsterdam: IOS Press.

23. Sirpal, R. (1994). Empirical Modeling of the Relative Impacts of Various Sizes of Shopping Centers on the Values of Surrounding Residential Properties. Journal of Real Estate Research, 9 (4): 487-505. DOI: 10.1080/10835547.1994.12090766.

24. Tonković, Ž. (2015). Trgovački centri i promjene u gradskoj jezgri: Slučaj Zadra. Sociologija i prostor, 53 (1): 3-20. DOI: 10.5673/sip.53.1.1.

25. Walker, A. (2014). Desire Lines Are the Real Future of Urban Transit. https://dailygrid.kinja.com/desire-lines-are-the-real-future-of-urban-transit-1566186934. (Pregledano 17. travnja 2019.)

26. Zhang, L.; Zhou, J.; Hui, E.; Wen, H. (2019). The Effects of a Shopping Mall on Housing Prices: a Case Study in Hangzhou. International Journal of Strategic Property Management, 23 (1): 65-80. DOI: 10.3846/ijspm.2019.6360.

27. Zlatar, J. (2011). Utjecaj trgovačkih centara (kao nemjesta) u Zagrebu na nestajanje javnog prostora, u: Čapo, J. i Gulin Zrnić, V. (Ur.). Mjesto, nemjesto - Interdisciplinarna promišljanja prostora i culture. Zagreb: Institut za etnologiju i folkloristiku.

\section{Izvori}

1. Arena Park (2019). O nama. https://www.arenapark.hr/hr/o-namal. (Pregledano 28. svibnja 2019.)

2. Balija, P. (2018). Ovo su ključni projekti koji će riješiti prometne gužve u Zagrebu!. Večernji list, ožujak 2018. https://www.vecernji.hr/ zagreb/radi-li-tuitko-ista-zaboravite-aute-buducnost-su-bicikli-1234105. (Pregledano 6. svibnja 2019.) 
3. Google Earth (2019). Satelitske snimke od 2005. do 2018. godine. https://earth. google. com/web/. (Pregledano 22. svibnja 2019.)

4. Grad Zagreb (2019). Velika obnova iz EU fondova. https://www.zagreb.hr/velika-obnova-iz-eu-fondova/107193. (Pregledano 6. svibnja 2019.)

5. Ministarstvo graditeljstva i prostornog uređenja (MGIPU) (2019). Informacijski sustav prostornog uredenja. https://ispu.mgipu.hrl. (Pregledano 15. svibnja 2019.)

6. Pološki, D. (2009). Rekonstrukcija raskrižja Jadranske i Dubrovačke avenije. Studija izbora rješenja. Zagreb: Aking d.o.o. - Građevinski fakultet.

7. Odjel za statistiku Gradskog ureda za strategijsko planiranje i razvoj grada (OZS) (2014). Popis 2011: Stanovnistvo, kućanstva i stanovi. http://www1.zagreb.hr/ zgstat/documents/POPIS\%202011/GZ stanovnistvo kucanstva stanovi/Popis2011_StanovniciKucanstvaStanovi_GradZagreb.pdf. (Pregledano 14. travnja 2019.)

8. Odjel za statistiku Gradskog zavoda za prostorno uređenje (OZS) (2005). Popis 2001: Stanovnistvo Grada Zagreba prema dobnoj i spolnoj strukturi; podaci po institucionalnim i funkcionalnim jedinicama. http://www1.zagreb.hr/zgstat/ documents/stanovnistvo gz \%20prema dobnoj spolnoj strukturi 2001/publikacija.pdf. (Pregledano 14. travnja 2019.)

9. Vitas Z (2017). Od kvarta na kraju grada do najatraktivnijeg zagrebačkog naselja. Večernji list, ožujak, 2017. https://www.vecernji.hr/zagreb/od-kvarta-na-krajugrada-do-najatraktivnijeg-zagrebackog-naselja-1157613. (Pregledano 6. svibnja 2019.)

10. Zagrebačka infrastruktura prostornih podataka (ZIPP) (2019). Korištenje zemljista. https://geoportal.zagreb.hr/. (Pregledano 16. travnja 2019.) 


\title{
Geography of Non-place: An Analysis of the Arena Centar in Zagreb (Macrolevel)
}

\author{
Karlo Mak \\ Antun Gustav Matoš Secondary School, Samobor, Croatia \\ e-mail:karlo.mak2@skole.hr \\ Martina Jakovčić \\ Faculty of Science of the University of Zagreb, Department of Geography, Croatia \\ e-mail:mjakovci@geog.pmf.hr
}

\begin{abstract}
Based on Augés concept of non-place, an interpretative model was designed for the analysis of the shopping mall (Microlevel) and the surrounding urban space (Macrolevel). De Certeau's concept of consumer production is used to establish a functional connection between the two levels. According to De Certeau, people are not merely passive consumers of space but build networks of resistance and thus participate in the creation of unstable spatial constellations. The model was applied to the case of the Arena Centar. This paper brings the results of research at a higher spatial level. It is based on transit markers that visitors of the mall leave in the surrounding space. These markers were detected by field research, mapping, photographing and the observation method. The analysis shows that the mall has a tendency to transform the surrounding space into a non-place, which can be seen in various spatial transitional marks as well as in dynamic morphological, functional, and demographic changes.
\end{abstract}

Key words: non-place, consumer production, shopping mall, Arena, Lanište, Jaruščica. 